\title{
Study of Marginal Microleakage in Root Caries Restored with Resin Composites, Giomers and Glass Ionomer Cements
}

\begin{abstract}
DAWOD NAZEM ${ }^{1}$, CORNELIA FLORENTINA BICLESANU', DOINA PALUTA ${ }^{1}$, STEFAN MANEA ${ }^{1}$, MONICA BANITA², VIOLETA HANCU ${ }^{1}$, ANAMARIA FLORESCU ${ }^{1}$

${ }^{1}$ Titu Maiorescu University of Bucharest, Faculty of Dentistry, Department of Dental Specialities, 67A Gheorghe Petrascu Str., 031593, Bucharest, Romania

${ }^{2}$ University of Medicine and Pharmacy of Craiova, Faculty of Dental Medicine, 2 Petru Rares Str., 200349, Craiova, Romania

Root decay is a complex and multifactorial disease. The aim of this study is to assess in vitro the sealing capacity of common aesthetic materials used to restore root caries as well as the size of the hybrid layer formed by SE-1 step vs 2-step ER adhesive techniques. For this study, 45 extracted teeth were used. After cleaning, near the enamel-cement junction, but at the level of the cementum, cavities were prepared and restored with resin composite, giomer and glass-ionomer cements. The teeth were covered with nail polish leaving uncovered the restoration area and $2 \mathrm{~mm}$ around it; teeth were kept for $24 \mathrm{~h}$, in $2 \%$ methylene blue. To assess the degree of marginal adaptation, SEM analysis was further performed. The association of 2-step ER adhesive system with giomers and resin composite shows the maximum adhesion efficiencyby forming a uniform, thick layer and dentinal tubules obliteration compared to SE-1 step adhesive system associated with the same restoration materials.
\end{abstract}

Key words root decay, adhesive systems, resin composite, SEM analysis

Root decays are considered a major oral health problem in the elderly. This hypothesis is argued by the increase in the average life of the population and the persistence on the oral arch of the teeth for a longer time associated with the periodontal recession process which is considered one of the triggering causes of the root decays.

Root decay is a complex and multifactorial disease. A more recent review of the literature has identified the following factors, organized in four areas, as responsible for root caries production: socio-demographic factor (age, gender, race/ethnicity), systemic health status (dementia), parameters in the intra oral area (number of teeth, bacterial plaque, bacterial species, dental caries index, loss of periodontal insertion, gingival recession, salivary flow) and behavioral ones (dental hygiene, brushing, smoking) [1].

The therapeutic management of root caries is based on the application of methods of prevention and remineralization of damaged dental structures to the detriment of the actual restoration techniques. The use of atraumatic restorative therapy (ART) is considered a viable solution due to its advantages of using hand tools without anesthesia and lesion restoration with a glass ionomer cement [2,3].

The restoration is done only when the cavity is formed and the age and the patient's health status are taken into account. Due to local anatomical features, various restorative materials and preparing techniques can be imployed. Thus, when restoration is done with nonadhesive materials, the preparation requires retention both on the cervical and apical walls; if restoration is done with resin composite, it is only performed in the apical wall, and when restoring with the glass ionomer cement it does not require physical retention. In this way, the clinical success appreciated through a correct marginal adaptation is in correlation with several factors such as morphological particularities, the preparation pattern and the category of restorative material used [4].

The aim of this study is to assess in vitro the sealing capacity of common aesthetic materials used to restore root caries as well as the size of the hybrid layer formed by SE-1 step vs ER 2-step adhesive techniques.

\section{Experimental part \\ Material and method \\ Tooth preparation}

For this study, 45 extracted teeth for orthodontic or periodontal reasons were used. After extraction, the teeth were cleaned of debris and then stored in physiological serum until the experiment was performed.

Near the enamel-cement junction, but at the level of the cementum, cavities were prepared according to the minimally invasive principles, using a high-speed diamond bur, under water cooling and a low speed round bur. The approximate dimensions of the cavities were $3 \mathrm{~mm}$ middistal, $4 \mathrm{~mm}$ occluso-cervical and $1.5 \mathrm{~mm}$ in depth.

\section{Tooth restoration}

Depending on the restoration material and the type of adhesive system, the teeth were divided into 3 groups ( $A$, $B, C$ ), with subdivision of the batches into 3 subgroups, in total resulted 9 groups with 5 teeth each and 10 restorations in each group (table 1).

The materials used in the study and in their composition are presented in table 2 .

The protocol for applying restoration materials was as follows (table 3):

(1) 2-step ER adhesive system protocol: Adper Single bond (3M Espe);

After the preparation of the cavity, etching acid (Scotchbond) was applied, which was kept on the tooth for $15 \mathrm{~s}$, then it was removed by washing for $10 \mathrm{~s}$. Next, excess water was removed and two consecutive Adper Single bond (3M Espe) adhesive layers were applied, which were gently dried for five seconds to evaporate the solvents and lightcured for $10 \mathrm{~s}$.

(2) 1-step SE adhesive system protocol: G-Bond (GC);

The adhesive was applied to the cavities, kept on the tooth for $10 \mathrm{~s}$, then dried for $5 \mathrm{~s}$ and $10 \mathrm{~s}$ of lightcuring was achieved.

\footnotetext{
* email: corneliabicle@yahoo.com; Phone: +40722636335
} 


\begin{tabular}{|c|c|c|}
\hline Study batch & Adhesive system & Restauration material \\
\hline \multirow[t]{3}{*}{$A$} & \multirow{3}{*}{$\begin{array}{l}\text { ER in } 2 \text { steps. } \\
\text { Adper Single bond ( } 3 \mathrm{M} \text { Espe); }\end{array}$} & - Composite resin Gradia Direct (GC \\
\hline & & $\begin{array}{l}\text { - Combination of giomer Beautifil flow plus and Beautifil II } \\
\text { (Shofu }\end{array}$ \\
\hline & & - Dyract compomer (DeTrey Dentsply). \\
\hline
\end{tabular}

\begin{tabular}{|c|c|c|}
\hline Study batch & Adhesive system & Restauration material \\
\hline \multirow[t]{3}{*}{$B$} & SE 1-step, G-Bond (GC); & - Composite resin Gradia Direct (GC. \\
\hline & & $\begin{array}{l}\text { - Combination of giomer Beautifil flow plus and Beautifil II } \\
\text { (Shofu. }\end{array}$ \\
\hline & & - Dyract compomer (DeTrey Dentsply. \\
\hline
\end{tabular}

Table 1

STUDY BATCHES

\section{Study batch \\ - Ketac Molar Easymix (3M Espe), self curing glass ionomer \\ - Glass Ionomer Base Cement (Shofu), self curing glass ionomer \\ - Hi Dense (Shofu), self curing glass ionomer with spherical particles of silver-tin alloy content}

Table 2

MATERIALS AND COMPOSITION

\begin{tabular}{|c|c|}
\hline Material & Composition \\
\hline $\begin{array}{l}\text { Gradia Direct (GC) } \\
\text { Microfilled Hybrid } \\
\text { Composite Resin }\end{array}$ & $\begin{array}{l}\text { Filler: Silica, Pre-polymerized filler, Flouroaluminosilicate glass } 65 \% \text { vol } \\
\text { Matrix: UDMA, Ethylen dymethacrylate }\end{array}$ \\
\hline $\begin{array}{l}\text { Beautifil II (Shofu) } \\
\text { A nano-hybrid composite } \\
\text { with fluoride release and } \\
\text { recharge }\end{array}$ & $\begin{array}{l}\text { Base resin: Bis-GMA }(7.5 \mathrm{wt} \%) / \text { TEGDMA }(5 \mathrm{wt} \%) \text { resin } \\
\text { Filler: Multifunctional glass filler and S-PRG filler based on fluroboroaluminosilicate glass. } \\
\text { Filler loading: } 83.3 \mathrm{wt} \%(68.6 \mathrm{vol} \%) \\
\text { Particle size range: } 0.01-4.0 \mu \mathrm{m} \\
\text { Mean particle size: } 0.8 \mu \mathrm{m} \\
\text { DL-Camphorquinone }\end{array}$ \\
\hline $\begin{array}{l}\text { Beautifil Flow Plus } \\
\text { A flowable nano-hybrid } \\
\text { composite with fluoride } \\
\text { release and recharge }\end{array}$ & $\begin{array}{l}\text { Base resin: Bis-GMA (15 wt } \%) / \text { TEGDMA (13wt } \%) \text { resin } \\
\text { Filler: Multifunctional glass filler and S-PRG filler based on fluroboroaluminosilicate glass. } \\
\text { Filler loading: } 67.3 \mathrm{wt} \%(47.0 \mathrm{vol} \%) \\
\text { Particle size range: } 0.01-4.0 \mu \mathrm{m} \\
\text { Mean particle size: } 0.8 \mu \mathrm{m} \\
\text { DL-Camphorquinone }\end{array}$ \\
\hline $\begin{array}{l}\text { Adper Single Bond Plus (3M } \\
\text { ESPE, St. Paul, MN, USA) } \\
\text { Adhesive ER in 2-steps }\end{array}$ & $\begin{array}{l}\text { Bis-GMA, HEMA, dimethacrylates, methacrylated polyalkenoic acid, copolymer, initiators, } \\
\text { water, ethanol and silane-treated silica nanofillers }\end{array}$ \\
\hline $\begin{array}{l}\text { G bond (GC) } \\
\text { Adhesive SE 1-step }\end{array}$ & $\begin{array}{l}\text { Filler particles } 7 \mathrm{~nm} \text {, ethanol, water, initiators besed on 4-META, UDMA, TEGMA, acetone, } \\
\text { distilled water. }\end{array}$ \\
\hline $\begin{array}{l}\text { Dyract (DeTrey Dentsply) } \\
\text { compomeer }\end{array}$ & $\begin{array}{l}\text { UDMA resin } \\
\text { TCB resin } \\
\text { Strontium fluoro silicate glass } \\
\text { Strontium fluoride } \\
\text { Photoinitiator } \\
\text { Stabilisers }\end{array}$ \\
\hline $\begin{array}{l}\text { Ketac Molar Easymix ( } 3 \mathrm{M} \\
\text { Espe), handmix glass } \\
\text { ionomer }\end{array}$ & $\begin{array}{l}\text { Powder: Calcium aluminum-lanthanumfluorosilicate glass, acrylic acid-maleic acid copolymer, } \\
\text { pigments } \\
\text { Liquid: Water, acrylic acid-maleic acid copolymer, tartaric acid }\end{array}$ \\
\hline $\begin{array}{l}\text { Hi Dense (Shofu) glass } \\
\text { ionomer }\end{array}$ & $\begin{array}{l}\text { Powder: Silicate aluminum and fluorosilicate glass, poliacrylic, tartaric, silver, titanium dioxide } \\
\text { Liquid: Water, acrylic acid, tricarboxylic acid }\end{array}$ \\
\hline $\begin{array}{l}\text { Glass lonomer Base Cement } \\
\text { (Shofu) }\end{array}$ & $\begin{array}{l}\text { Powder: Alumino fluoro silicate glass } 85 \% \text {, Barium sulphate } 15 \% \\
\text { Liquid: Copolymer of acrylicacid and tricarboxylic acid (Water solution) }>90 \% \text {, Tartaric acid }< \\
10\end{array}$ \\
\hline
\end{tabular}


Table 3

OPERATING PROTOCOL

\begin{tabular}{|c|c|c|}
\hline Restauration material (batch $\mathrm{A}+\mathrm{B}$ ) & Batch A & Batch B \\
\hline Gradia Direct (GC) resin composite, applied in one & \multirow{4}{*}{$\begin{array}{l}\text { Adhesive system: } \\
2 \text { step ER. Adper Single bond } \\
\text { (3M Espe); } \\
\text {-Etching for } 15 \mathrm{sec} \text {., washing, } \\
\text { mild drying; } \\
\text {-Adper Single bond, light-cured } \\
\text { for } 10 \text { seconds }\end{array}$} & \multirow{4}{*}{$\begin{array}{l}\text { Adhesive system: } \\
\text { 1-step SE, G-Bond (GC); the } \\
\text { adhesive is applied for } 10 \\
\text { sec., then it is dried for } 5 \mathrm{sec} \text {. } \\
\text { and light-cured for } 10 \\
\text { seconds }\end{array}$} \\
\hline layer and light-cured for 20 seconds & & \\
\hline $\begin{array}{l}\text { Beautifil flow plus si Beautifil II (Shofu) giomers, } \\
\text { each layer light-cured for } 20 \text { seconds }\end{array}$ & & \\
\hline $\begin{array}{l}\text { Dyract Compomer (DeTrey Dentsply) applied in } \\
\text { one layer and light-cured for } 20 \text { seconds }\end{array}$ & & \\
\hline
\end{tabular}

\section{Study batch C}

Study batch $\quad$ Restauration material

\begin{tabular}{l|l}
\hline+ & Ketac Molar Easymix (3M Espe), glass ionomer self photopolymerizable \\
Conditioner is applied $(10 \mathrm{~s})$; it is rinsed with lots of water; it is mildly dired ( $5 \mathrm{~s})$; the surface must \\
remain wet. In ration of 4,5 are mixed powder (1 powder dose): 1part water (1 drop) with a plastic \\
spatula, up to 30 seconds; They are applied on the tooth surface.
\end{tabular}

spatula, up to 30 seconds; They are applied on the tooth surface.

Glass Ionomer Base Cement (Shofu), glass self photopolymerizable ionomer: mix powder with liquid in ratio $2.6 \mathrm{~g} / 1.0 \mathrm{~g}$ (one dose + one drop) in 2 steps, max. $60 \mathrm{sec}$., Maximum working time is $2 \mathrm{~min} 30 \mathrm{sec}$.

Hi Dense (Shofu), glass ionomer self photopolymerizable with spherical silver-tin alloy premixed particles

\begin{tabular}{|l|l|}
\hline Score & Appearance \\
\hline 0 & Without impregnation \\
\hline $1=$ Minimum impregnation & infiltration $1 / 3$ in the depth of cavity \\
\hline $2=$ Moderate impregnation & infiltration $1 / 3$ up to $2 / 3$ in the depth of cavity \\
\hline $3=$ Severe impregnation & infiltration over $2 / 3$ in the depth of cavity near the axial or pulp wall \\
\hline
\end{tabular}

Table 4

ASSESSING THE INFILTRATION DEGREE
(3) For the restoration of teeth in groups $A$ and $B$, different materials were used: composite resin Gradia Direct (GC), single layer applied and lightcured for $20 \mathrm{~s}$, combination of Beautifil flow plus and Beautifil II (Shofu) giomers, each layer being lightcured for $20 \mathrm{~s}$ and Dyract compomer (DeTrey Dentsply) applied in one coat and lightcured for $20 \mathrm{~s}$

(4) Restored teeth with glass ionomer cements

For restorations, cements were applied in one coat following the manufacturer's recommended preparing and insertion guidelines. The materials used are Ketac Molar Easymix (3M Espe), Glass lonomer Base Cement (Shofu), Hi Dense (Shofu).

After the restoration, the teeth were finished and polished (using diamond burs at high speed and water spray) then placed in distilled water and kept until the next experimental step ( $24 \mathrm{~h}$ ). Using carbide and diamond burs with high speed and water spray for finishing composite restorations don't seem to have a detrimental effect on the joint between enamel and composite resin [5].

Further, the protocol consisted of isolation of: teeth with nail polish leaving uncovered the restoration area and $2 \mathrm{~mm}$ around it; teeth insertion, for $24 \mathrm{~h}$, in $2 \%$ methylene blue; toothbrushing and toilets to remove the superficial methylene blue solution; cutting teeth with a diamond disk, at low speed, under cooling with water.

The assessment of marginal infiltration was made by the assessment according to the scores presented in table $4[6]$.

To assess the degree of marginal adaptation, SEM analysis was further performed after dehydration and sample preparation.

\section{Results and discussions}

The results obtained after inserting the teeth into $2 \%$ methylene blue are shown in figures 1-9.

Batch A (Adper Single bond adhesive system)

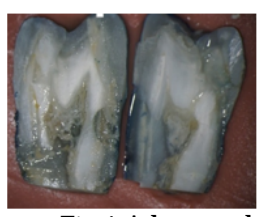

Fig 1 Adper and giomer

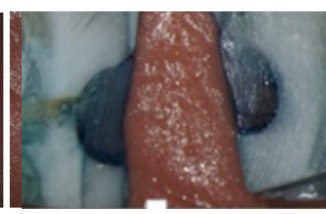

Fig.2. Adper and composite

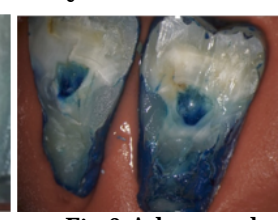

Fig.3 Adper and compomer

Batch B (G-bond adhesive system)

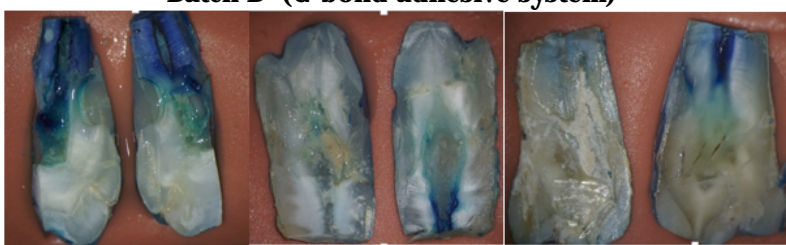

Fig.4 G-bond and composite

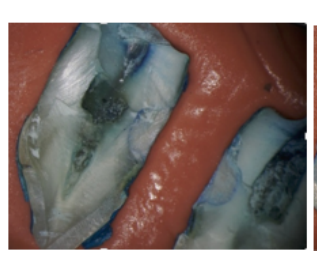

Fig. 7 Ketac Molar
Fig.5 G-bond and compomer

Batch C

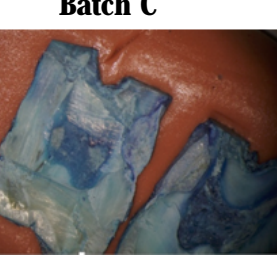

Fig. 8 Shofu Hi Dense Fig. 9 Shofu Base 


\begin{tabular}{|c|c|c|c|c|c|c|}
\hline $\mathrm{Nr}$ & Materials & $\begin{array}{l}\text { Score } 0 \\
\%\end{array}$ & $\begin{array}{l}\text { Score } 1 \\
\%\end{array}$ & $\begin{array}{l}\text { Score } 2 \\
\%\end{array}$ & $\begin{array}{l}\text { Score } 3 \\
\%\end{array}$ & $\begin{array}{l}\text { Total } \\
\%\end{array}$ \\
\hline 1 & Adper Single bond + Gradia direct & 7 & 2 & 1 & $\begin{array}{l}0 \\
0 \%\end{array}$ & $\begin{array}{l}10 \\
100 \%\end{array}$ \\
\hline 2 & $\begin{array}{l}\text { Adper Single bond + Beautifil flow } \\
\text { plus and Beautifil II }\end{array}$ & 8 & 1 & 1 & $\begin{array}{l}0 \\
0 \%\end{array}$ & $\begin{array}{l}10 \\
100 \%\end{array}$ \\
\hline 3 & $\begin{array}{l}\text { Adper Single bond } \\
+ \text { Dyract }\end{array}$ & 5 & 3 & 2 & 0 & $\begin{array}{l}10 \\
100 \%\end{array}$ \\
\hline \multirow[t]{2}{*}{4} & G-Bond + & 4 & 4 & 1 & 1 & $\begin{array}{l}10 \\
100 \%\end{array}$ \\
\hline & G Gradia direct (GC) & & & & & \\
\hline 5 & $\begin{array}{l}\text { G-Bond }+ \\
\text { Beautifil flow plus and Beautifil II }\end{array}$ & 4 & 1 & 5 & $\begin{array}{l}0 \\
0 \%\end{array}$ & $\begin{array}{l}10 \\
100 \%\end{array}$ \\
\hline 6 & $\begin{array}{l}\text { G-Bond } \\
\text { Dyract }\end{array}$ & 3 & 4 & 2 & 1 & $\begin{array}{l}10 \\
100 \%\end{array}$ \\
\hline 7 & Ketac Molar & 1 & 2 & 3 & 4 & $\begin{array}{l}10 \\
100 \%\end{array}$ \\
\hline 8 & Glass Ionomer Base Cement & 0 & 1 & 2 & 7 & $\begin{array}{l}10 \\
100 \%\end{array}$ \\
\hline 9 & Hi Dense & 0 & 1 & 3 & 6 & $\begin{array}{l}10 \\
100 \%\end{array}$ \\
\hline
\end{tabular}

Table 5

SCORES PRESENTATION

From the infiltration point of view, the restoration with Adper Single bond (3M Espe) + Beautifil flow plus and Beautifil II (Shofu) gave the best results ( 0 score, no infiltration), the infiltration of methylene blue was minimal (score 1) for Adper Single bond (3M Espe) + Gradia Direct (GC) and Dyract (DeTrey Dentsply) as well as the G-Bond + Dyract combination (DeTrey Dentsply), teeth that have been restored with Glass Ionomer Base Cement, Hi Dense (Shofu) were more impregnated (score 3). Infiltration was moderate (score 2) for Ketac Molar Easymix (3M Espe) and G-Bond + Beautifil flow plus and Beautifil II (Shofu) only in the rootarea.

The batch distribution on the scores and the type of material is presented in table 5 .

The SEM analysis revealed the following aspects of the adhesion performance shown in figures 10-27.

The goals of root decays treatment are to restore the structural loss caused by the carious process, to protect the pulp and to prevent the occurrence of secondary caries.

Restoration of the root caries presents a series of difficulties represented by periodontal and pulp aspects,

\section{Batch A}

Sample 1. Adper Single bond adhesive and Beautifil giomers

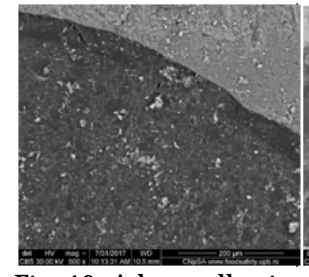

Fig. 10. Adper adhesive and Beautifil, 500x magnification. Dentin tubules of irregular size, with irregular, laced wall, with the obliteration

presence (some seem completely sealed, others show a halo between the material and peritubular dentin)

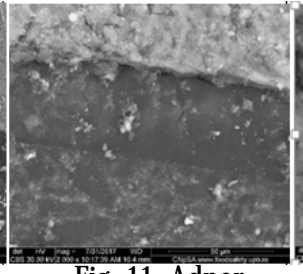

Fig. 11. Adper adhesive and Beautifil, enlarged 2000x. The width of the hybrid layer is about $50 \mu \mathrm{m}$. It is seen that the area of dentinal tubules is cross-sectional in irregular shape, laced and the presence of smear plugs at the entrance into larger canals
Sample2 Adper adhesive and Gradia direct resin composite

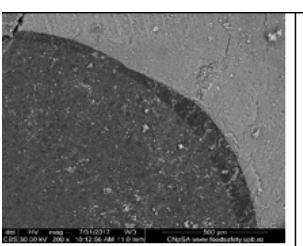

Fig. 13. Area of resin composite- adhesive system-dentin, 200x magnification.Very good dissemination of the material on the surface of the dentin.

The appearance of dentinal tubules is more homogeneous, of regular size, with wellcontoured walls, net outline.

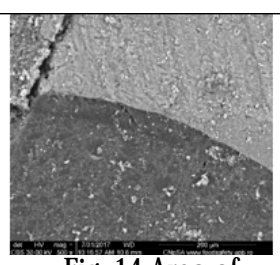

Fig. 14 Area of resin compositeadhesive systemdentin, 500x

magnification Hybrid

layer of 40-50 $\mathrm{um}$.

\section{distribution of
particles that \\ penetrate and} obliterate dentinal tubules

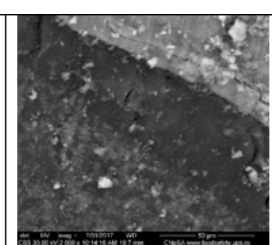

Fig. 15. Area of resin composite- adhesive system-dentin, 2000x magnification. Homogeneous

\section{Sample 3 Adper adhesive and Dyract compomer}

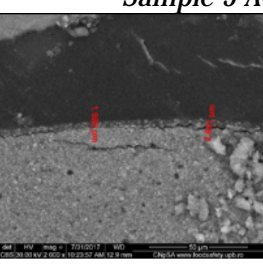

Fig. 16. Compomer area - adhesive system, 2000x magnification. We observe the

formation of a hybrid layer of adhesivecompomer approx. 2-3 $\mu \mathrm{m}$

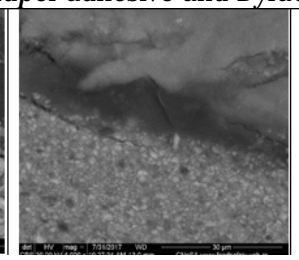
area - adhesive system- dentin, 4000x magnification. The undefined hybrid zone, festooned.
Fig.17. Compomer

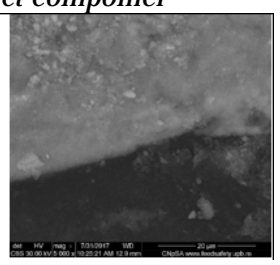

Fig. 18. Adhesive system-dentin area at $5000 x$
Adher and

Beautifil, 5000x magnification. The material particles are spread evenly over the section surface isolation, retention, access, visibility, post operative sensitivity, anatomic features.

In root injuries involving cement and dentin walls, the polymerization shrinkage of the composite resin can lead to the formation of voids at the restoration interface/ dental structure level. 
Batch B

Sample 4 G-bond adhesive and Beautifil giomers

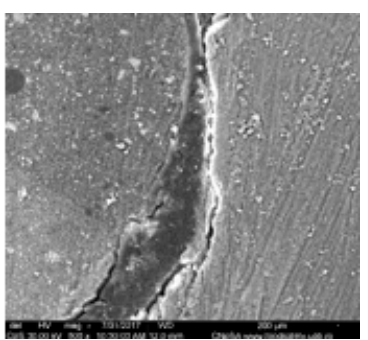

Fig. 19. Giomer -G bond adhesive system- hybridized smear layerdentin area, magnified $500 \mathrm{x}$.

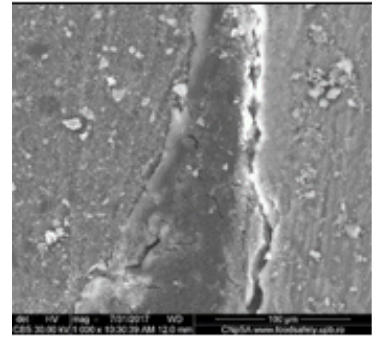

Fig. 20. G-bond adhesive and Beautifil giomer, magnified 1000x. It can be noticed the presence of the continuation solution between the two interfaces

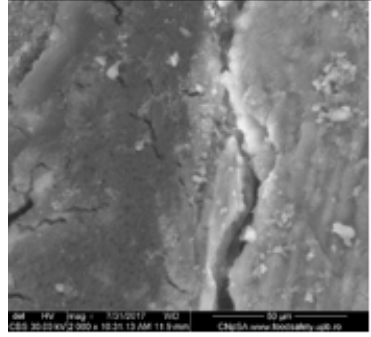

Fig. 21. Area of adhesive system- hybridized smear layer - dentin, magnified at 2000x. It can be noticed the presence of pores in the adhesive system. It seems to be a low adhesive area, with deep crevasses and branched out of the adhesive system pores. It can also be a technique error with too strong dehydration

Sample 5 G-bond adhesive and Gradia direct composite

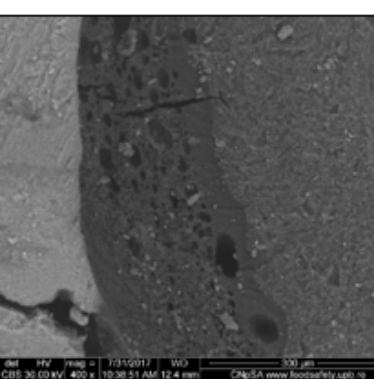

Fig. 22. Dentin area - bonding system $G$ bond - composite resin, 400x magnification. At the adhesive layer level, pores of variable sizes are observed. The presence of dentinal tubules and their branches with partial obliteration with modest particles is evidenced

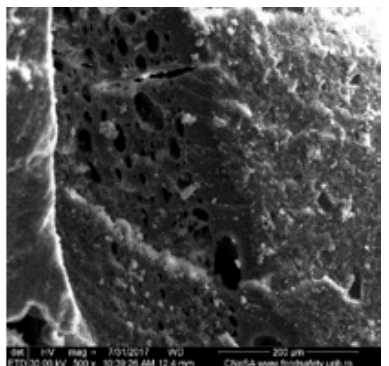

Fig. 23. Dentin- hybridized smear layer - adhesive system - composite resin area at 500x. On the left there is the dentin with good particle covering

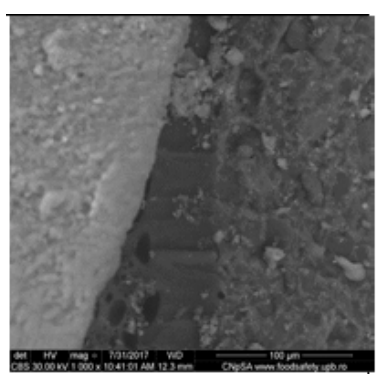

Fig. 24. G-bond adhesive and Gradia direct composite, 1000x magnification.

Sample 6 G-bond adhesive and Dyract compomer

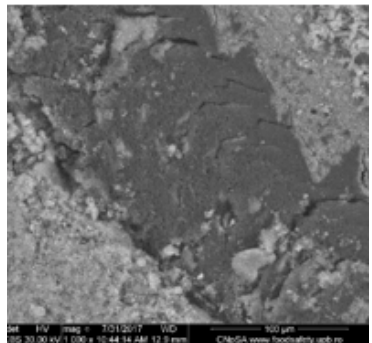

Fig. 25. Dentin- hybridized smear layer- adhesive system- compomer, 1000x magnification. It seems to be a well-organized hybrid layer, thickness $20 \mu \mathrm{m}$.

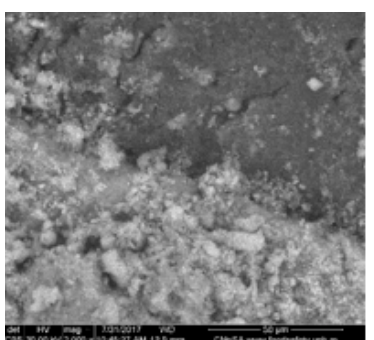

Fig. 26. Dentin- hybridized smear layer - adhesive system - compomer at $1000 x$.

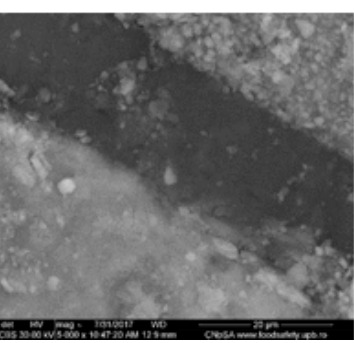

Fig. 27. Dentin- hybridized smear layer - adhesive system - compomer at 5000x. The material looks very well and homogeneously structured in particles of approximately equal size, which seem to seal the dentinal tubules in the lower part of the image.

Demineralization of peritubular dentin.

\section{Batch C}

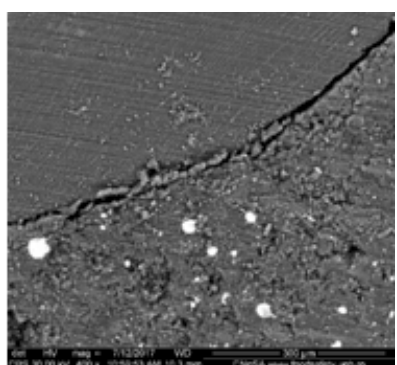

Fig. 28. CIS HiDense Shofu. The mixed layer seems fractured on both sides, modest size, under $10 \mu \mathrm{m}$.

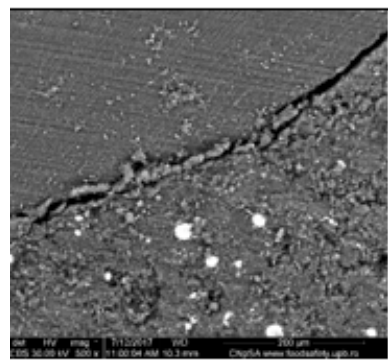

Fig. 29. Non-homogeneous dentin may be an area of Tomes granular layer

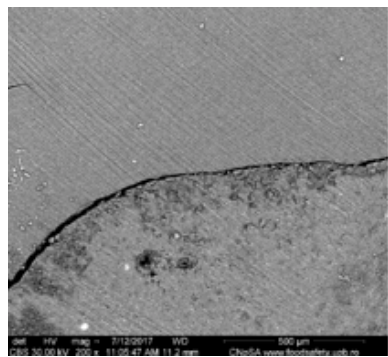

Fig. 30. CIS Base, $200 x$ surface dentin magnification with dentinal tubules and collateral branches

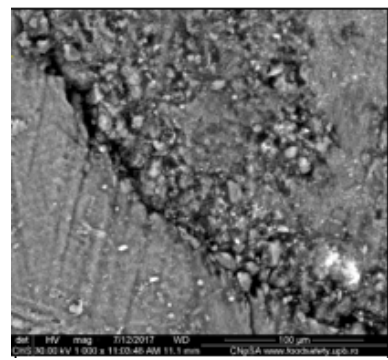

Fig. 31. CIS Base, dentin 1000x magnification with dentinal tubules and collateral branches, small particles of material inside 


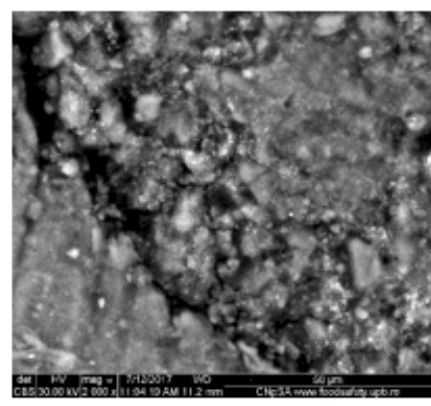

Fig. 32. CIS Base, magnification 2000x.

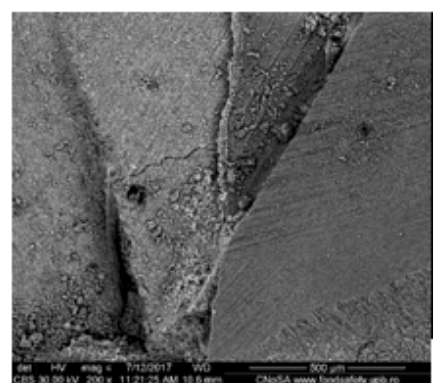

Fig. 33. CIS Ketac Molar, 200x magnification. The preparation is fractured, the mixed area 20-30 $\mu \mathrm{m}$

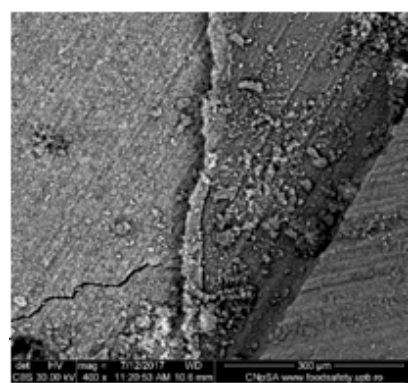

Fig. 34. CIS Ketac Molar, magnification 400x.

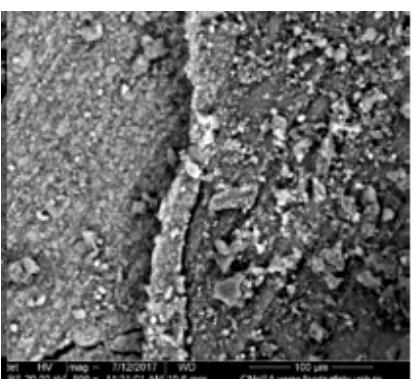

Fig. 35. CIS Ketac Molar, magnification 800x. Large fragments of material that appear to be superficially located and small fragments in the dentinal tubules in the

longitudinal section.

In this study, teeth restored with composite resins, giomers and compomers in combination with 2- step ER and 1- step SE adhesives as well as self polymerizable glass ionomer cement were used for the evaluation of marginal adhesion and microleakage.

The test by which the sealing capacity of a restoration material is checked is maintaining marginal adaptation. To determine the degree of marginal microleakage in this study we used $2 \%$ methylene blue. This colorant is highly water-soluble and penetrates the dental structures, plus it has a low molecular weight (about $0.52 \mathrm{~nm}^{2}$ ) compared to the diameter of the dentinal canals $(1-4 \mu)$ and the bacteria $(2-4 \mu)$ and easily penetrates dentinal canals imitating the passage of bacterial toxins into them [7].

In the present study, marginal microleakage was present to some extent in almost all the restoration materials used, the glass ionomer exhibiting a maximum infiltration followed by composites, giomers and compomers which showed better results with minimal infiltration. These data are consistent with the study by Sayed HYEl et al. which showed that the marginal microleakage of glass ionomer cement, composite and compomer restorations was evident in all restoration materials [8].

Glass ionomer cement has a lower sealing capacity and among the three cements used in this study, Ketac Molar has a slight superiority compared to the other two cements (Glass Ionomer Base Cement, Hi Dense).

Glass ionomer cement has many qualities that recommend it as the ideal material for the restoration of the root caries because it performs a chemical retention with the dental structure, releases fluoride throughout the retention period [3].

However, glass ionomer cement has poor sealing capacity when used to prevent marginal microleakage. The presence of smear layeras well as the polymerization shrinkage may affect the sealing capacity of the glass ionomer cement [9]. Higher infiltration capacity at the level of the teeth restored with glass ionomer cement could be attributed to inappropriate condensation with the incorporation of air bubbles. The glass ionomer cements used in the study are self-polymerizable, so preparation is done extemporaneously by combining a powder with a liquid. This preparation method cannotaccurately measure the quantities of the mixture while the encapsulated preparations are not subject to such errors. This may be the explanation for glass ionomer cements showing a less tight marginal adaptation compared to Dyract [10].

In addition, water loss from the composition of glass ionomer cement results in a porous aspect with microscopic cracks. To prevent this, it is important that the cement is protected with varnish or grease (petroleum jelly). In this context, studies show that the failure of a glass ionomer cement occurs inside it rather than at the glass ionomer cement /tooth interface. So, determining the adhesion force of glass ionomer cement is actually

measuring the resistance to cement stretching. This force is relatively low in freshly prepared cement, but increases in time [3].

Other authors reported frequent voids and fractures at the interface with gingival wall as well as cohesive fractures, concluding that all types of failures are present in glass ionomers cements, when using them in opensandwich technique [11].

In this study, microleakage was minimal when Adper Single bond (3M Espe) + Dyract (DeTrey Dentsply) as well as the G-Bond + Dyract combination (DeTrey Dentsply) were used. But, in class V compomer-filled cavities, Rominu showed that microleakeage at the gingival interface could be significantly reduced by aditional silane treatmentof previously acid etched dentin [12].

Resin composites are the first restoration materials that maintain marginal integrity over a clinically acceptable period [13].

The advantage of using composites to restore rootcaries is the ability to adhere without mechanical retention, and the disadvantages are the need for good isolation, good visibility, furthermore the adhesion to dentin is inferior to adhesion to enamel.

Acid etching, the application of a low viscosity bonding agent and the provision of perfect insulation should be routine procedures for all composite resin restorations [13]. The composite material used in this study is Gradia Direct (GC). Gradia Direct is a lightcuring hybrid composite that contains pre-polymerized micro-particles, a coupling agent and dimethacrylate urethane as a matrix. This product offers significant advantages in aesthetics, finishing, wear and tear resistance as well as a lower susceptibility to polymerization shrinkage. All of these factors can contribute to the good performance of composite materials in this study.

The giomers are new, effective restorative and adhesive dental materials with a high capacity of both fluoride release and recharge with it, biocompatible and aesthetic. For these reasons, they are the ideal material for restoring the defects of the root area. The giomer concept is based on pre-reacted glass ionomer (PRG) technology.

Adhesive agents in the study used are 2-step ER Adper Single bond (3M Espe) and SE 1-step, G-Bond. Adper Single bond (3M Espe) is a fifth generation adhesive system. It removes the smear layer, enlarges the dentinal tubules and demineralizes the intratubular dentin. Primer moistens the collagen fibers, which leads to the formation of the hybrid layer.

G-Bond is a 7th generation (single component) adhesive system that combines acid and adhesive technology with superior chemical and mechanical adhesion. Self-etching 
adhesives do notrequire a separate etching phase because they contain an acid monomer in a solution of water or HEMA-based adhesive. The separate tooth rinse phase is eliminated because these systems contain water that is never completely removed from the tooth.

For these reasons, the marginal adaptation of a restoration depends, in addition to the type of material or techniques of polymerization, on the use of different adhesive systems. The composite material is associated with a different microleakage depending on the adhesive technique.

In this study, SEM analysis shows that ER Adper Single bond (3M Espe) and Gradia Direct (GC) resin composite exhibits maximum adhesion efficiency.

SEM analysis conducted in their study by Qi CZ and etal. shows that ER adhesive achieves a better bond to enamel compared to SE adhesives, but the bond to dentin and cement did not show any significant difference [14].

In this context, in another study, the authors concluded that marginal integrity of enamel increased significantly when ER adhesive systems and composite resin were used; the marginal integrity of dentin increased significantly in composite restorations using SE. Both the marginal seal of enamel and dentin increased significantly by using an SE adhesive system instead of the glass ionomer cement conditioner [6].

In the present study, the association of Adper Single bond (3M Espe) with the Beautifil flow plus and Beautifil II (Shofu) is the most beneficial, the study shows that there is no marginal microleakage. The result is consistent with Santos et al. which in their study showed that the ER adhesive system presented the best resistance to dentin, concluding that these adhesive systems are superior to SE adhesives [15].

This result is, however, inconsistent with some literature studies that show that AdperTM Single Bond adhesive system provides a lesser marginal adaptation to the greater presence of marginal microleakage compared to SE 1 step GBond. In this context it is supported the idea that there is a higher degree of microleakage at the gingival margin compared to occlusal one [16, 17].

In this study, the association of G-Bond (GC) with composites or compomers has been shown to have inferior results compared to the results obtained by associating the same materials with the ER 2 step technique. However, in this association the study showed that infiltration was present only at enamel-cementum jonction.

The results are in agreement with other studies that suggest that the SE 1-step technique (G-Bond (GC)) has less marginal sealing capacity compared to the ER 2 step Adper Single bond (3M Espe) technique $[18,19]$.

Although the ER adhesive system has shown better values in a meta-analysis by Masarwa $\mathrm{N}$ et al., compared to the SE system, the authors did not find any significant difference in the longevity of the restorations made with the two types of adhesive techniques [20].

The adhesive layer should act as an elastic pad against various stresses, with many factors affecting its stiffness/ elasticity. These include the modulus of elasticity of its components, the thickness of the hybrid layer and the degree of interaction between its components [21] and the type of monomer it makes up. The presence of bisphenol glycidyl methacrylate (BIS-GMA) makes the adhesive more rigid due to its high molecular weight compared to other monomers, such as urethane dimethacrylate (UDMA) and triethylene glycol dimethacrylate (TEGDMA).
Thus, the absence of BIS-GMA from GC Bond makes the adhesive layer more elastic and more tolerant of stress compared to Adper adhesive system.

The results of Carrera's recent research have shown that the mean adhesion strength with SE $(14.9 \pm 1.9 \mathrm{MPa})$ waS significantly higher than ER Adper Single Bond (12.9 \pm 3.0 $\mathrm{MPa})(p<0.05)$; Most specimens $(91.3 \%)$ presented a pattern of adhesion failure and fractures along the resin composite-dentine interface. SE failed mainly at the dentine-adhesive interface, while ER Adper Single Bond at the composite-adhesive interface [22].

Due to the high degree of hydrophilicity, SE 1-step lightcuring adhesives have been shown to act as permeable membranes, allowing water to pass through the adhesive layer.

For SE 1-step adhesives without HEMA (G bond) a complex phase separation process was reported in which water is separated from other adhesive components. This process is determined by gradual evaporation of the organic solvent (usually ethanol and acetone) with bubble formation in the adhesive layer. It is obvious that the incorporation of the bubbles may contribute to the degradation of adhesion, but persistence of the water in the adhesive layer can also negatively affect the adhesion $[23,24]$.

In the presentstudy, the association of Adper Single bond (3M Espe) with Beautifil flow plus and Beautifil II (Shofu), but also with Gradia direct composite, resulted in the formation of a strong hybrid layer of approx. $50 \mu \mathrm{m}$, with the uniform dissemination of the particulate material on the dentin surface, as well as the obliteration of the dentinal tubules.

Instead, associating G-bond with the same restoration materials formed a much smaller hybrid layer of about 20 $\mu \mathrm{m}$ with the presence of pores and partial obliteration of dentinal tubules.

In agreement with this, Albaladejo concludes that ER adhesive systems have thicker layers than those formed in self-etched adhesive systems but both were continuous and uniform in thickness, and the all-in-one adhesive used in his study showed the formation of droplets between the adhesive and composite resin; they may occur as a result of the absorption of dentine water through osmosis and may interfere with the polymerization process of the resin [23].

Other studies, that used Adper Single Bond as an adhesive in combination with the Filtek $\mathbf{Z 2 5 0}$ composite resin, revealed an average thickness of the $8-12 \mu \mathrm{m}$ in the hybrid layer [25].

Studies show that the hybrid layer formed by SE 1 step measures $3-5 \mu \mathrm{m}$ and resin tags of approximately $2-3$ $\mu \mathrm{m}$. Both the length of the resin tags in the dentine as well as the thickness of the hybrid layer produced by the 7th generation adhesives are lower compared to the fifthgeneration adhesives. This can be determined by the weak etching used in SE techniques (GC Bond) [21].

The adhesion after use of the ER system is much deeper compared to the effect produced by the 7th generation of SE adhesives and the adhesive interface is more uniform in SE containing the acidic monomer which dissolves the hybrid layer [26,27].

As far as the compomers are concerned, in this study Adper adhesive and Dyract compomer formed an adhesivecompomer hybrid layer of approx. 2-3 $\mu$ m indefinitely delimited, festooned. Instead, the G-bond adhesive associated with the same compomer formed a wellorganized, homogeneous hybrid layer, $\sim 20 \mu \mathrm{m}$ thick, with approximately homogeneous particles that seem to seal the dentinal tubules well. 
It is true that self-etching adhesives exhibit lower adhesion resistance values, but the advantages of simplicity of the technique and elimination of rinsing and drying steps cannot be ignored. In this way, the possibility of over-wetting or over-drying, which are detrimental to the integrity of the interface, is reduced. Future clinical studies are needed to confirm that these characteristics are important to the longevity of restoration [28].

\section{Conclusions}

The present study was conducted to assess the performance of root restorations in vitro by analyzing the adhesion resistance achieved with aesthetic restorative materials.

The association of Adper Single bond (3M Espe) with Beautifil flow plus and Beautifil II (Shofu) and Gradia Direct (GC) composite shows the maximum adhesion efficiency by forming a uniform, thick layer and dentinal tubules obliteration compared to G-Bond adhesive (GC) associated with the same restoration materials.

Simple techniques, moderate etching and low sensitivity, in addition to its performance, make the clinical choice of 7th generation adhesives an advantage.

\section{References}

1. RITTER, AV., SHUGARS, DA., BADER, JD., Community Dent Oral Epidemiol.,38, nr. 5, 2010, p.383-97

2. EC, L., LUO, Y., TAN, HP., DYSON, JE., CORBET, EF., J Dent Res., 85, 2006, p. 929-932.

3. SIDHU, SK., NICHOLSON, JW., J Funct Biomater.,7, nr.3, 2016, p. 215.

4. DONALD, LC., SHYUE, C., Decisions in dentistry, 03, 2016, p. 24-7 5. IOVAN, G., STOLERIU, S., PANCU, G., NICA, I., SANDU, AV., ANDRIAN,

S., TANCULESCU, O., Mat. Plast., 54, no.2, 2017, p.375

6. KHOROUSHI, M., KARVANDI, TM., KAMALI, B., MAZAHERI, H., Indian J Dent Res.,23, 2012, p.378-83

7. HELENO, JFG. et all., Dental Press Endod., 2, nr.2, 2012, p.30-6. 8. SAYED, H., ABDALLA, Al., SHALBY, ME., Tanta Dental Journal, 11, nr.3, 2014, p.180-188

9. WATSON, TF. et all., Dental materials, 30, 2014, p.50-61.
10. PRABHAKAR, AR., MADAN, M., RAJU, OS., J. Indian Soc. Pedo. Prev. Dent.,21, nr.2, 2003, p.45-48.

11. GHIORGHE, CA., IOVAN, G., ANDRIAN, S., NICA, I, TOPOLICEANU, C., PANCU, G., Rev. Chim. (Bucharest), 68, no.8, 2017, p.1890

12. ROMINU, M., FLORITA, Z., ROMINU RO., SINESCU, C., NEGRUTIU, ML., PETRESCU, EL., POP, DM., ENESCU, M., TUDOR, A., Rev. Chim. (Bucharest), 62, no.8, 2011, p. 849

13. SHETTY, K., et all. Dental Science, 7, nr. 6, 2015, p. 607-611.

14. QI, CZ., JIANG, Y., LI, SY., LIN, Y., FAN, XM., YU, Q., Shanghai Kou Qiang Yi Xue, 20, nr.3, 2011, p. 260-4.

15. SANTOS, RA., et all., RGO, Rev Gauch Odontol, Porto Alegre.,62, nr.4, 2014, p.365-370.

16. GUPTA, A., et all. J Clin Diagn Res.,11, nr.4, 2017, p. ZC53-ZC56.

17. TABARI, M., ESMAEILI, B., ALIMOHAMMADI, M., BEJ ER MIR, AP., GHAREKHANI, S., HAJIAHMADI, M., et all., Caspian J Dent Res., 3, 2014, p.14-19.

18. VAN LANDUYT, KL., DE MUNCK, J., MINE, A., CARDOSO, MV., PEUMANS, M., VAN MEERBEEK, B.,J Dent Res., 89, 2010, p.1045-50.

19. SARR, M., KANE, AW., VREVEN, J., MINE, A., VAN LANDUYT, KL., PEUMANS, M., et all., Oper Dent, 35, 2010, p.94-104.

20. MASARWA, N., et all., J ournal of Evidence Based Dental Practice, 16, nr.2, 2016, p.96-106

21. ELIGUZELOGLU, E., ERASLAN, O., OMURLU, H., ESKITASCIOGLU, G., BELLI, S., Eur J Dent., 4, nr.2, 2010, p.160-5.

22. CARRERA, CA., CHEN, YC., LI, Y., RUDNEY, J., APARICIO, C., FOK, A., J ournal of Dentistry, 52, 2016, p.37-44.

23. ALBALADEJO, A., OSORIO, R.,TOLEDANO, M., FERRARI, M., Med Oral Patol Oral Cir Bucal, 15, nr.1, 2010, p. el12-8.

24. SAURO, S., PASHLEY, DH., MANNOCCI, F., TAY, FR., PILECKI, P., SHERRIFF, M., et all., Eur J Oral Sci., 116, 2008, p.184-93.

25. SAVEANU, Cl., DANILA, I., J ournal of Romanian Medical Dentistry,14, nr.2, 2010, p.148-51.

26. GANGADARAN, V., PALANISWAMY, M., BALASUBRAMANIAN, M., J Indian Acad Dent Spec Res., 2, nr. 1, 2015, p.5-7

27. TOUMA, L., YASSIN, O., Iran J Public Health, 44, nr.6, 2015, p.885886

28. MARTINS, GC., et all. Eur J Dent., 6, nr.2, 2012, p.169-177

Manuscript received: 26.10 .2017 